IZA DP No. 6528

Urban-Rural Disparities of Child Health and Nutritional Status in China from 1989 to 2006

Hong Liu

Hai Fang

Zhong Zhao

April 2012 


\title{
Urban-Rural Disparities of Child Health and Nutritional Status in China from 1989 to 2006
}

\author{
Hong Liu \\ Central University of Finance and Economics, Beijing \\ Hai Fang \\ University of Colorado at Denver \\ Zhong Zhao \\ Renmin University of China \\ and IZA
}

Discussion Paper No. 6528

April 2012

IZA
P.O. Box 7240
53072 Bonn
Germany

Phone: +49-228-3894-0

Fax: +49-228-3894-180

E-mail: iza@iza.org

\begin{abstract}
Any opinions expressed here are those of the author(s) and not those of IZA. Research published in this series may include views on policy, but the institute itself takes no institutional policy positions.

The Institute for the Study of Labor (IZA) in Bonn is a local and virtual international research center and a place of communication between science, politics and business. IZA is an independent nonprofit organization supported by Deutsche Post Foundation. The center is associated with the University of Bonn and offers a stimulating research environment through its international network, workshops and conferences, data service, project support, research visits and doctoral program. IZA engages in (i) original and internationally competitive research in all fields of labor economics, (ii) development of policy concepts, and (iii) dissemination of research results and concepts to the interested public.
\end{abstract}

IZA Discussion Papers often represent preliminary work and are circulated to encourage discussion. Citation of such a paper should account for its provisional character. A revised version may be available directly from the author. 


\section{ABSTRACT}

\section{Urban-Rural Disparities of Child Health and Nutritional Status in China from 1989 to 2006}

This paper analyzes urban-rural disparities of China's child health and nutritional status using the China Health and Nutrition Survey data from 1989 to 2006. We investigate degrees of health and nutritional disparities between urban and rural children in China as well as how such disparities have changed during the period 1989-2006. The results show that on average urban children have 0.29 higher height-for-age z-scores and 0.19 greater weight-forage $z$-scores than rural children. Urban children are approximately $40 \%$ less likely to be stunted $(\mathrm{OR}=0.62 ; \mathrm{P}<0.01)$ or underweight $(\mathrm{OR}=0.62 ; \mathrm{P}<0.05)$ during the period 19892006. We also find that the urban-rural health and nutritional disparities have been declining significantly from 1989 to 2006. Both urban and rural children have increased consumption of high protein and fat foods from 1989 to 2006, but the urban-rural difference decreased over time. Moreover, the urban-rural gap in child preventive health care access was also reduced during this period.

\section{HIGHLIGHTS}

- Urban children have better health and nutritional status than rural children in China.

- However, the urban-rural child health and nutritional disparities declined significantly from 1989 to 2006.

- Both urban and rural children increased consumption of high protein and fat foods.

- The urban-rural difference in high protein and fat food consumption decreased over time.

- The urban-rural gap in child health care access was also reduced over time.

JEL Classification: I14, I15

Keywords: child, health and nutritional status, urban-rural disparities, China

Corresponding author:

Hai Fang

University of Colorado at Denver

13001 E. 17th Place

Aurora, CO 80045

USA

E-mail: hai.fang@ucdenver.edu 


\section{Introduction}

Previous studies have shown the existence of various health disparities between urban and rural areas in the United States, Canada, Australia, China, and other countries in health status, health access, and health utilization (AHRQ, 2005; Pong et al., 2009; Liu et al., 1995; Van de Poel et al., 2007). Urban-rural health disparities are expected to be even more pronounced in China, since the central as well as local governments still implement policies that are preferential towards urban areas (Zhang and Zou, 2012), and the health care systems in China have been entirely different for urban and rural populations for the past 60 years. Moreover, China enforces a residence registration system (hukou) to restrict internal migration, which creates distortions in labor markets. It discriminates against migrants and inhibits the expected returns from narrowing of wage/income differentials we would expect from a free movement between urban and rural areas. Liu et al. (1999) find a widening gap in health status between Chinese urban and rural residents during the period 1985-1993, which is correlated with increasing inequalities of income and health care utilization. Changes in the health care system and financing mechanisms have been identified as being among the most important reasons for these increasing health disparities.

Children are expected to be more severely affected by urban-rural health care system disparities, because they are in the early stages of body growth. Several previous studies have provided strong evidence supporting this argument. Shen et al. (1996) use five sets of cross-sectional data between 1975 and 1992 in China and find that the height difference between urban and rural children has been increasing since China's Reform and Opening Policy in 1978. Furthermore, Luo et al. (2009) examine the differences of height and body mass index of youth in urban vs. rural areas in Hunan province (an agricultural province), and show that urban youth are significantly taller and heavier (in terms of BMI) than their rural counterparts in the 1990s and 2000s. Based on the WHO growth reference of 2007, the stunted prevalence for children and adolescents in 2002 was $16.4 \%$ in rural China, but $5.7 \%$ in urban China 
(Li et al., 2009).

It is well documented that child malnutrition is an important indicator of poor child health status, which is strongly associated with high mortality risk (Black et al., 2003; Rice et al., 2000). Childhood malnutrition is also associated with poor health outcome, educational performance, and labor market outcomes in later life (Jamison, 1986; Alderman et al., 2003; Manary and Sandige, 2008), so reducing child malnutrition has been listed as one of the United Nations' Millennium Development Goals (MDGs) (UN Millennium Project, 2005).

In China, nutrition intake has also been found to be one of the most important factors for all the health disparities between urban and rural China (Chang et al., 1994). For example, fat intake is essential to children's growth, but children in rural China are found to have substantially lower fat intake than their urban counterparts in the 1990s (Chen, 2000). Morgan (2000) finds that, despite of considerable regional variations, the average heights of school-age children increased significantly from 1979 to 1995 . Recent evidence also suggests that the prevalence of child malnutrition declined substantially in China between 1992 and 2002 (Bredenkamp, 2009). Besides nutrition intake, differences in the extent of health care seeking behavior in urban and rural China are also a key explanation for the rural-urban health disparity among children (Hesketh et al., 2003).

China has made tremendous economic achievements, but this economic development does not necessarily reduce inequalities of health status, nutrition, and health care services (Hsiao and Liu, 1996). In fact, though the differences in height between rural and urban children narrowed from 1975 to 1985, they widened again from 1987 to 1992 (Shen et al., 1996).

Motivated by the above facts, this paper aims at examining the urban-rural disparities of China's child health and nutritional status using data from 1989 to 2006. Our study makes three contributions to the existing literature. First, we aggregate seven waves of data from the China Health and Nutrition Survey (CHNS) to study the trend of urban-rural child health and nutritional disparities from 1989 to 2006. Specifically, we not only investigate whether urban children have better health and 
nutritional status than rural children, but also characterize how such difference has changed during the period 1989-2006. Second, we apply Blinder-Oaxaca decomposition to explore the extent to which urban-rural differences in child health and nutritional status reflects a variety of observed socioeconomic and demographic indicators or an unobserved component. Finally, in order to help understand the changing urban-rural gap in child health and nutritional status, we also examine two possible linkages: whether urban children are better off than rural children in terms of major food-group consumption and preventive health care utilization, and how these two factors between urban and rural areas are changing over time.

\section{Materials and Methods}

\subsection{Data}

We use data from the China Health and Nutrition Survey (CHNS), collected by the Carolina Population Center at the University of North Carolina Chapel Hill and the National Institute of Nutrition and Food Safety in the Chinese Center for Disease Control and Prevention. The CHNS is an ongoing project providing rich data to study social and economic changes in both urban and rural China, and their effects on the economic, demographic, health, and nutritional status of the Chinese population. The CHNS employs a multistage, random cluster sampling procedure to draw the sample from nine provinces in China, including Guangxi, Guizhou, Heilongjiang, Henan, Hubei, Hunan, Jiangsu, Liaoning, and Shandong. In the first three waves (1989, 1991, and 1993), Heilongjiang Province was not included. In the wave of 1997, Liaoning Province was excluded. In each sampled province, counties are initially stratified as low, middle, and high income, and then four counties are randomly selected based on a weighted sampling scheme to provide the rural sample. The provincial capital and a low-income city are selected when feasible to provide the urban sample. Villages and townships within the sampled counties, and urban and suburban neighborhoods within the sampled cities, are selected randomly. In 1989-1993 there were 190 primary sampling units (including 32 urban neighborhoods, 30 suburban neighborhoods, 32 
towns and 96 rural villages), and a new province (Heilongjiang) and its sampling units were added in 1997 . Since 2000, the primary sampling units have been increased to 216 (including 36 urban neighborhoods, 36 suburban neighborhoods, 36 towns, and 108 villages). In each community, 20 households were randomly selected and all household members were interviewed, but only preschoolers and young adults aged 20-45 years were surveyed in 1989 due to constraints of funding.

CHNS is an unbalanced panel data. There are 3795 households in first round of the CHNS conducted in 1989. The 1991 CHNS surveyed only individuals belonging to the original sample households, and the 1993 CHNS added new households formed from sample households, resulting in a total of 3441 households. Since 1997, new households in original communities were also added to replace households no longer participating in the study, and some new replacement communities were also added in each round of the CHNS.

Sampling weights are not available for researchers to make these data representative of China or of these nine survey provinces ( 8 provinces from 1989-1997). This is because "the State Statistical Office of China would not share their sample frame with the CHNS team" when the survey was planned and implemented, and the CHNS data collectors could not create their own sampling weights (CHNS 2012). Although CHNS is not a nationally representative data set in China, it is still a good large database to show the health development of individuals from 1989 to 2006. The response rate was high in various waves, on average $88 \%$ at individual level and 90\% at household level (Popkin et al., 2009). In addition, China currently has 32 provinces or province equivalent administrative units, and these 9 sample provinces in CHNS vary widely regarding geography, economic development, public resources, and health indicators and host approximately $45 \%$ of China's total population.

The present study utilizes the first through seventh waves of the CHNS data: 1989, 1991, 1993, 1997, 2000, 2004, and 2006, so we can examine trends of health and nutritional disparities for children from 1989 to $2006 .{ }^{1}$ We analyze children under the

\footnotetext{
${ }^{1}$ The eighth wave of the CHNS data was collected in 2009 and is partly available at present, but data on child height and weight have not been released yet when the present study is analyzed. So we are not able to include 2009
} 
age of 18 in each wave. ${ }^{2,3}$ Starting with a sample of 21,870 child respondents, we exclude those with missing data on height and weight, or implausible height-for-age and weight-for-age $z$-scores (exceeding 10 in absolute value; 37 respondents) from the analysis. The final study sample is a pooled cross sectional data set with 15,719 observations, including 604 observations in 1989, ${ }^{4} 3,285$ observations in 1991, 3,295 observations in 1993, 2,813 observations in 1997, 2,492 observations in 2000, 1,525 observations in 2004, and 1,705 observations in 2006.

\subsection{Variables}

The main dependent variables are child health and nutritional status, measured by height-for-age $z$-score (HAZ), weight-for-age $z$-score (WAZ), ${ }^{5}$ and the anthropometric outcomes of being stunted or being underweight, using children in urban China as the reference population (Ministry of Health, 2005). ${ }^{6}$ A child whose height-for-age $z$-score

wave of CHNS data.

${ }^{2}$ It is well documented that the nutritional status in early childhood and preschool period is of great importance (Ruel, 2010; Victora et al., 2010; Ruel et al., 2008; Abdeen et al., 2007; Anderson, 1979), and nutrition intervention may have significant long-term economic consequences (Hoddinott et al., 2008). Although there have been limited studies examining adolescents' malnutrition and the long-term cognitive and health effects, recent studies show that malnutrition in adolescents is also serious in developing countries (Cordeiro et al., 2005; Delisle et al., 2001; Kurz and Johnson-Welch, 1994). Studies show that individuals can gain 15\% of their ultimate adult height and $50 \%$ of their adult weight during adolescence, which is accompanied by an increasing demand for nutrients and energy (Heald and Gong, 1999). Other evidence (i.e. Case et al. (2002)) suggests that malnourishment during growth spurts has a bigger effect on height than malnourishment at other periods. Therefore, we include all children from 0 to 18 . Moreover, we also conducted the analysis for different age groups, and the results are very similar.

${ }^{3}$ According to the previous literatures, girls begin adolescent growth spurt at around 9 years and grow at peak velocity of about $8 \mathrm{~cm} /$ year at about 11-12 years. Boys start growth spurt at around 1.5-2 years later with a maximum growth velocity of about $9.5 \mathrm{~cm} /$ year (Abassi, 1998; Murasko, 2011). So the general growth spurt period is 9-14 for girls and boys.

${ }^{4}$ The health and nutritional data were collected only from preschoolers in CHNS 1989, so the sample size for wave 1989 is much smaller than the other waves. Accordingly, we have conducted some sensitivity analyses. First, we find similar trend of urban-rural health difference for children if excluding wave 1989. Second, if we restrict the study sample to pre-school children using CHNS 1989-2006, we also find a similar trend of urban-rural health differences. The results of sensitivity analyses are available from the authors upon request.

${ }^{5}$ The $z$-scores are calculated as the difference between actual height (weight) and mean height (weight) divided by the standard deviation in the reference children population of same age and gender.

${ }^{6}$ We also use the reference standards of the World Health Organization (WHO) growth chart to compute 
is less than -2 is classified as being stunted, and one whose weight-for-age $z$-score is less than -2 is classified as being underweight. Being stunted is considered as the measure of long-term nutritional deficiency, and underweight reflects acute shortages of food.

The key independent variable is whether a child resides in an urban or a rural area (URBAN dummy), and is constructed from the original sampling-unit variables. The primary sampling units of CHNS are communities from cities, county towns, suburban villages, and rural villages of China, which are all entities officially identified by the National Bureau of Statistics of China. Based on the criterion used for administrative purposes, the definition of urban areas in China is an urban district, city and town with a population density more than $1500 / \mathrm{km}^{2}$ (National Bureau of Statistics of China, 2000). ${ }^{7}$ Following this administrative definition, the CHNS classifies city neighborhoods and county town neighborhoods as urban areas and classifies suburban and rural villages as rural areas. Jones-Smith and Popkin (2010) developed an urbanicity index on a continuum for China using CHNS data, ${ }^{8}$ including 12 components such as population density, economic activity, traditional markets, modern markets, transportation infrastructure, sanitation, communications, housing, education, diversity, health infrastructure, and social services. They find that the average score for cities and county towns (the urban sample) are significantly higher than those for suburbs and villages (the rural sample). This indicates that the rural sample in CHNS does come from areas with rural features.

Besides the URBAN dummy, we also control for other covariates that could potentially affect child health and nutritional status. Health insurance coverage is a binary indicator showing whether the child has health insurance at the survey time.

Z-scores, and the results (not reported here) are very similar. Since the weight standards are only available for children from 0 to 10 years in WHO Reference 2007, we report the results using the reference from 2005 China Health Statistics, which can be used for all the children aged from 0 to 18.

7 This differs somewhat from the US definition of an urban location, which has been defined as a densely populated area consisting of 50,000 or more people (US Census Bureau, 2009).

8 We try regressions using the continuous urbanization index as the key independent variables, and also find a decreasing trend of urban-rural health disparities for children. It shows that our results are robust to the binary measure of urban/rural status. The results using urbanization index are available from the authors upon request. 
Individual demographic variables include age, gender, Han nationality dummy (Han is the largest ethnic group in China), student status, household income per capita, gender of household head, and household size. We also control for parents' demographic and socioeconomic characteristics if parents' information is available in the data, including parents' age, height, BMI, education, employment status, and health behaviors, as well as indicators for missing mother and missing father. Health behaviors are measured by two set of binary variables indicating whether the mother or father smokes cigarettes at the survey time, and whether the mother or father has drunk any alcoholic beverage in the previous year. In addition, three indicators for survey periods (1989-1993, 1997-2000, and 2004-2006) are included to reflect the time trend of child health and nutritional status, as we find that the patterns of health disparities for the above three time periods are significantly different. Dummy variables for the nine provinces are also added to control for regional differences that may be associated with child health and nutritional status.

This study also specifies two linkages that may help to understand the changing trend of urban-rural child health and nutritional disparities: child daily major food-group consumption and preventive health care utilization. We examine the consumption of three major food groups at the individual level, including cereals, meat and poultry, and eggs. They are among the top food sources of dietary fat for Chinese residents (Guo et al., 2000). The CHNS nutrition survey provides data on individual daily food consumption for three interview days in each survey year. We calculate the total three-day consumptions of each of the three major food groups as proxies for child nutrition intake, ${ }^{9}$ and use the natural logarithms of these consumptions to correct the right skewness of these variables.

Preventive health care utilization is measured by a dichotomous variable indicating whether the respondent has received any preventive health service, such as a health examination, eye examination, or blood test, during the previous 4 weeks; data on preventive health service over longer periods are not available in CHNS data.

\footnotetext{
${ }^{9}$ Although these food-group consumptions may not provide children all necessary nutrients, they are still good proxies for child nutrition intake.
} 


\subsection{Empirical Method}

We begin our analysis by comparing measures of child health and nutritional status as well as other explanatory variables between urban and rural samples, using pooled CHNS data for 1989-2006. We use the chi-square test for dichotomous variables and Student's $t$-test for continuous variables to examine whether the urban-rural differences are statistically significant, and report their $P$-values.

We then conduct multivariate regression analyses using the pooled cross sectional data to study urban-rural disparities of child health and nutritional status after controlling for the confounding variables. ${ }^{10}$ Ordinary least squares estimation is employed for the continuous outcome variables (height-for-age and weight-for-age $z$-scores), and logit estimation is used for dichotomous outcome variables (being stunted and underweight). Standard errors are clustered at the household level. Then, we use Blinder-Oaxaca decomposition techniques and multivariate analyses to explain urban-rural health and nutritional disparities for children in China.

The Blinder-Oaxaca decomposition method divides the health and nutritional disparities between urban and rural children into a part that can be explained by differences in the levels of observed covariates such as socioeconomic and demographic characteristics controlled in the regression, and a residual part that cannot be accounted for by any observed differences in the covariates (Blinder, 1973; Oaxaca, 1973; Fairlie, 2005). Multivariate OLS and logistic Blinder-Oaxaca decomposition techniques are used for the continuous and dichotomous outcome variables, respectively. The Blinder-Oaxaca decomposition results may depend on the choice of the omitted base group (Jones, 1983; Oaxaca and Ransom, 1999). Our decomposition results use the coefficients from a pooled regression over both groups as the reference coefficients, and include a group indicator in the pooled model as an additional

\footnotetext{
${ }^{10}$ Our empirical method follows the previous literatures on child health as well as urban-rural health difference in China (Case et al., 2002; Currie and Stabile, 2003; Bredenkamp, 2009; Chen and Li, 2008; Fang et al., 2009a).
} 
covariate (Neumark, 1988). ${ }^{11}$

In order to explore the dynamic evolution of urban-rural health and nutritional disparity from 1989 to 2006 , we conduct multivariate regression analyses by adding interaction terms between the dummy variable URBAN and the three time period dummies as defined above, to identify the changing trends of urban-rural disparities and also to check their statistical significance level. Moreover, we also perform the multivariate regression analyses for the three time periods 1989-1993, 1997-2000, and 2004-2006 separately. The magnitudes of our estimated coefficients on the URBAN dummy in each regression are compared to describe the urban-rural disparities in child health and nutritional status, and to sketch the changes of these disparities over time.

To understand the mechanisms that underlie urban-rural child health and nutritional disparities in China, we also examine the urban-rural disparities in two sets of variables relevant to child health and nutritional status: child daily major food-group consumption (including cereals, meat/poultry, and eggs) and preventive health care utilization. We choose not to include these two sets of variables in the multivariate analyses for child health and nutritional status, ${ }^{12}$ because of the simultaneity among contemporary food intake, health care use and child health and nutritional outcomes. And these outcome variables are highly correlated. For example, the correlation coefficients of egg consumption and all four measures of health and nutritional outcomes range from 0.4 to 0.8 in magnitude and are significant at the $1 \%$ level We implement OLS estimation for the three continuous outcomes of natural logarithm of child daily food-group consumption, and logistic estimation for the binary outcome of preventive health care utilization. The independent variables include URBAN dummy, child's characteristics, household characteristics, parents' demographic and socioeconomic characteristics, and indicators of provinces.

11 To test the robustness, we also use the average coefficients over both groups as the reference coefficients (Reimers, 1983; Yun, 2005), and the decomposition results (not reported here) are very close to our main results.

12 One more reason for not including these two sets of variables in the main regressions is because a large number of missing data on child daily food consumption may lead to a substantial reduction of sample size and raise concerns about the representativeness of our study sample. 


\section{Results}

\subsection{Descriptive Results}

Table 1 presents the descriptive statistics of variables used in this study for the entire sample as well as for the urban and rural samples. Urban children account for approximately $24 \%$ of the sample. Urban and rural children were significantly different in almost all the outcome and control variables. Compared with urban children, rural children had lower height-for-age and weight-for-age $z$-scores, and a higher proportion of being stunted and/or underweight. All of these differences are statistically significant with $P<0.001$. Moreover, urban children consumed more meat and poultry, and eggs, but less cereals than rural children. The percentage of urban children receiving preventive health service during the previous 4 weeks was also higher than that of rural children ( $7 \%$ vs. $4 \%$ ). The descriptive results thus suggest that rural children in China had lower health and nutritional status. Table 1 indicates that the urban parents were also quite different from rural parents in their socioeconomic and demographic characteristics. The most obvious is the huge difference in education attainments. $60 \%$ of mothers had primary education or less compared with $27 \%$ for urban mothers; $46 \%$ of urban fathers had upper middle school or college education compared to only $18 \%$ of rural fathers.

\section{(Insert Table 1 Here)}

\subsection{Multivariate Regression Analyses}

Table 2 reports the results of multivariate analyses for the urban-rural disparities in child health and nutritional status, after controlling for the confounding variables listed in Table 1. In the estimation, we pool the seven waves of data and include binary indicators for three time periods: $1989-1993,1997-2000$, and $2004-2006 .{ }^{13,14}$ After controlling for other confounding variables, urban children had 0.29 higher

\footnotetext{
${ }^{13}$ If we include dummy variables for each survey wave, the results are almost the same.

${ }^{14}$ Some coefficients and odds ratios are not reported here for the sake of brevity, but the full regression models are available from the authors upon request.
} 
height-for-age $z$-scores than rural children, and had 0.19 greater weight-for-age $z$-scores. The coefficients are statistically significant at the $1 \%$ level. To facilitate the interpretation of our results, we translate these $z$-scores into actual height and weight of boys at age 9. The differences in height and weight were 1.77 centimeters, and 1.08 kilograms, respectively. Our analysis indicates that urban children were about $40 \%$ less likely to be stunted $(\mathrm{OR}=0.62 ; P<0.01)$ or underweight $(\mathrm{OR}=0.62 ; P<0.05)$ than their rural counterparts. The coefficient of interest may not be interpreted as a causal effect, but as an association.

\section{(Insert Table 2 Here)}

\subsection{Decomposition Analyses}

Table 3 provides the results using Blinder-Oaxaca decomposition technique to determine the relative importance of observed versus unobserved components in accounting for urban-rural disparities. The results suggest that both observed and unobserved components are significant, though the former are slightly more important. More specifically, the predicted height-for-age $z$-scores are -0.93 for rural children and -0.31 for urban children. Of this total difference of $0.62 z$-score unit, the observed variables in the model can explain 0.33 ; the other 0.29 is due to the unobserved component. Results for weight-for-age $z$-scores are similar. In the logistic decomposition analysis for being stunted, the total difference in predicted probability of being stunted between rural and urban children is 10 percentage points, of which about 6 percentage points can be explained by the observed factors, and the remaining 4 are attributed to the unobserved factors. There are similar findings for the outcome of being underweight.

\section{(Insert Table 3 Here)}

\subsection{Trend Analyses from 1989 to 2006}

Figure 1 shows the urban and rural trends of child health and nutritional status from 1989 to 2006. The raw urban-rural gap in height-for-age and weight-for-age z-scores persisted during this period, but narrowed slightly for height-for-age z-score 
during 2004-2006. The urban-rural gap in the prevalence rates of being stunted and/or underweight declined over time from 1989-2006.

(Insert Figure 1 Here)

To examine the time trend of urban-rural child health differences after controlling for the confounding variables, Panel 1 in Table 4 provides multivariate evidence with interaction terms between time dummy variables and the variable URBAN, and Panel 2 presents the results of the multivariate regression analyses separately for each of the three survey periods 1989-1993, 1997-2000, and 2004-2006. ${ }^{15}$

(Insert Table 4 Here)

Panel 1 in Table 4 shows that urban children's height-for-age $z$-scores were 0.33 higher than that of rural children in the period 1989-1993, but the difference declined by $0.01 z$-score unit from the period 1989-1993 to the period 1997-2000 (statistically insignificant), and decreased significantly by $0.17 z$-score unit $(P<0.05)$ from the period 1989-1993 to the period 2004-2006. Consistently, urban children had low probability of being stunted $(\mathrm{OR}=0.6 ; P<0.01)$ in the period $1989-1993$ compared with rural children, but the difference declined significantly from the period 1989-1993 to 2004-2006. There was no significant time trend of the urban-rural difference in weight-for-age $z$-scores and the probability of being underweight.

The results in Panel 2 of Table 4 show that urban children had higher height-for-age $z$-scores and a lower probability of being stunted than rural children, but the urban-rural gaps declined from 1989 to 2000, and became statistically insignificant in the period 2004-2006. For example, the difference in height-for-age $z$-scores decreased from 0.35 to 0.26 , and further to 0.09 (insignificant). The weight disparity was persistent but also decreased over time. Urban children's weight-for-age $z$-scores were 0.18-0.19 units higher than rural children's during 1989-2000, and the difference declined to 0.13 units for 2004-2006 (only significant at the $10 \%$ level). The odds ratio

\footnotetext{
${ }^{15}$ We report only selected coefficients here for ease of exposition, but the full set of regression results is available from the authors upon request.
} 
for the variable URBAN in the regression of being stunted changes from 0.59 during 1989-1993, to 0.63 during 1997-2000, and further to 0.84 (insignificant) during 2004-2006. It indicates that urban children were about $40 \%$ less likely to be stunted than rural children in the period 1989-1993, but the urban-rural difference became insignificant in the period 2004-2006. Children residing in urban areas were less likely to be underweight than those in rural areas in the period 1989-1993, but were no longer significantly different during 1997-2006.

As a robustness check, we also conduct multivariate regression analyses to examine the trend of urban-rural health disparities for boys and girls separately. As shown in Table 5, the results suggest that the urban-rural health difference narrowed for both boys and girls from 1989 to 2006.

(Insert Table 5 Here)

\subsection{Two Linkages}

Table 6 shows the multivariate analyses of major food-group consumption and preventive health care use for children from 1989 to 2006 . This table may provide insights into the urban-rural disparities in child health and nutritional status. ${ }^{16}$

(Insert Table 6 Here)

The results in Panel 1 of Table 6 suggest that urban children consumed significantly more meat and poultry by $21 \%$, more eggs by $6 \%$ than rural children in the period 1989-1993, and the changes of these differences were insignificant from 1989 to 2006. The common trend of these two food-group consumptions was increasing for both rural and urban children. Although urban children consumed fewer cereals than rural children in 1989-1993 and the difference decreased over time, the common declining trend of cereal consumption indicates nutrition transition toward a relative high protein/fat food diet for urban and rural children, and even more changes for rural children. Moreover, consistent with Panel 1, the results in Panel 2 also show that the urban-rural difference in children's consumption of meat and poultry was

\footnotetext{
${ }^{16}$ For ease of exposition, we only report selected coefficients, but the full set of regression results is available from the authors upon request.
} 
decreasing from $24 \%$ in $1989-1993$ to $20 \%$ in $2004-2006$. This may provide one potential explanation for the declining trend of urban-rural gap in child health and nutritional status.

As shown last column of Table 5, urban children were about 2.5 times more likely to use preventive health care than rural children in the early 1990s. But the difference declined from 1997 to 2006. Consistently, comparing the results using different time periods of data, we find that the odds of urban children using preventive health care declined substantially from 1989 to 2006 and became statistically insignificant during the period 1997-2006. In the last period of our sample, both urban and rural children had the same likelihood of utilizing preventive health care.

Because of the simultaneity among contemporary food intake, preventive care use and child health and nutritional outcomes, we choose not to control for child food consumption and preventive health care use in our main results reported in the paper (Table 2). To make the linkages between food consumption, preventive care use and child health, we also try an alternative estimation by adding them as the covariates in a sensitivity analysis. ${ }^{17}$ The sample size is around one third of those for the main regressions in Table 2, due to substantial missing data about child food consumption. The results suggest that the coefficient on urban indicator decreases by one third in the magnitude in the regression for height $\mathrm{z}$-score, and the consumption of meat and poultry is significantly associated with better child health. It is also found that the decreasing trend of urban-rural health differences becomes insignificant in pooled regressions with interaction terms between time dummy variables and urban indicator, but still statistically significant when we conduct multivariate regressions separately for each survey period. These findings also imply that the changes of child food consumption and preventive care use may help explain the decreasing trend of urban-rural disparity.

\subsection{Other Findings}

\footnotetext{
17 The results are available from the authors upon request.
} 
Beside the main findings summarized above, our analysis has yielded some other interesting findings. Table 2 shows that children's health and nutritional status are positively associated with health insurance coverage, household income per capita, parents' height and BMI, and parents' education. All the results in Table 2 and Table 4 suggest that there were significant improvements in health and nutritional status for both rural children and urban children from 1989 to 2006.

We control for regional difference associated with child health and nutritional status, using provincial dummies although unreported in the table. The results suggest that children in the northeastern province Heilongjiang and coastal province Jiangsu had no significant difference in health and nutritional status from those in the northeastern province Liaoning (the reference province). Children in the coastal province Shandong had significantly lower height-for-age $\mathrm{z}$ scores and thus higher probability of being stunted than those in Liaoning. But children in Shandong had higher weight-for-age $\mathrm{z}$ scores and thus lower probability of being underweight than children in Liaoning. Compared to children in Liaoning, children in the central provinces, such as Henan, Hubei, and Hunan, had lower z scores of height-for-age and weight-for-age, and were also associated with higher probability of being stunted; and children in western provinces, including Guangxi and Guizhou, were worse in all four health and nutritional outcomes.

Our results also indicate that the gender difference in child health and nutritional status is modest in both rural and urban samples. As shown in Table 2, girls had a slightly higher height-for-age $z$-score (by 0.04 units), and a lower probability of being stunted $(\mathrm{OR}=0.91)$, although the differences are insignificant. Boys and girls exhibited no significant differences in weight-for-age $z$-scores and/or in the probability of being underweight. These results indicate that the definition and construction of $z$-scores has captured the biological difference between genders, which accounts for most of the gender differences in child growth.

We have also conducted multivariate analyses by gender and with interaction terms between dummy variable URBAN and gender. The results are in upper Panel of Table 7. They suggest that the urban-rural differences in height and weight $z$-scores 
were more pronounced for boys than for girls. However, the differences in the stunted and/or underweight probabilities were larger for girls than for boys. These results also hold if we run regressions separately for boys and girls (see the lower Panel of Table 7).

(Insert Table 7 Here)

\section{Discussions and Conclusions}

The present study shows that urban children in China have better health and nutritional status than rural children, but the differences have declined significantly from 1989 to 2006. These findings are robust to bivariate analyses, multivariate analyses of cross-sectional data, and multivariate analyses of 7 waves' data with interaction terms. Our results about China's urban-rural gap in child growth are consistent with earlier studies (Shen, 1996; Luo et al., 2009; Dearth-Wesley et al., 2008). However, to our knowledge, this is the first study to investigate the evolution of the differences from 1989 to 2006. The declining trend of urban-rural difference in child health and nutritional status is also consistent with the study by Van de Poel et al. (2009), which also find narrowing urbanicity-related inequalities in both overweight

and hypertension for adults from 1991 to 2004 using CHNS data. The rural-urban difference of weight-for-age $z$-scores is smaller than that of height-for-age $z$-scores, which is also consistent with the finding in Smith et al. (2005) based on data from 36 developing countries.

This study may be subject to some limitations. First, due to data limitations, we mainly use anthropometric indicators to measure child health and nutritional status. But child health status is multidimensional and nutritional status is only one important dimension. Second, children of rural migrants cannot be identified separately in the study, because the migrants are not surveyed in the CHNS data (Fang et al., 2009a). Third, the sample size of aggregating 7 waves of the CHNS data may not be large enough, given the huge regional differences in socioeconomic status in CHNS. However, a dataset for children in China from 1989 to 2006 is difficult to find. CHNS 
data provides us a good opportunity to conduct a 17-year's study on the trend of child health and nutrition status in China.

There are several potential explanations for the declining trends of urban-rural disparities. First, since 1990, China was changing from one facing food shortage and malnutrition to one with increasing obesity, especially in urban areas (Du, 2002; Dearth-Wesley et al., 2008; Fang et al, 2009b). Although the total energy intake decreased slightly over time, food diversity and high protein/fat food consumption increased considerably in both urban and rural China (Du et al., 2002; Popkin and Du, 2003; Wang et al., 2002). We also find that although urban children still consume more meat, poultry and eggs than rural children from 1989 to 2006, the common trend of these food-group consumptions is increasing for both urban and rural children. The urban-rural gap in children's consumption of meat and poultry is decreasing over time, which may lead to the declining trend of urban-rural gap in child health and nutritional status.

We have examined the relative price change of high protein food versus rice, using 2006 adjusted free market price for pork, eggs and rice from the CHNS community survey. Consistent with our results about child food consumption, there is a common trend in both urban and rural communities that eggs became cheaper relative to rice from 1989 to 2006 . The relative price of pork versus rice increased from about 4 in 1989 to 7 in 1997, and then decreased to 4.5 in 2006. This finding suggests the protein/fat rich foods have become cheaper relative to rice, which helps explain the decreasing intake of cereals and increasing intake of protein/fat rich food in both urban and rural diet.

In addition, as shown in the literatures, there are rising health problems associated with overeating or the overconsumption of certain foods or food components (Du et al., 2002; Popkin and Du, 2003). Previous studies show that overweight and obesity are more prevalent in urban children than in rural children (Chen, 2000; Yang, 2007; Li et al., 2009), and the control and prevention of overweight and obesity are more important in urban China (Li et al., 2009).

The second explanation is that with China's health system reform since 1998, 
urban-rural gap in health care access is significantly improved for children. Despite of the disintegration of the rural cooperative medical systems (CMS) in the early 1980s (Dong, 2009), Chinese government tried to re-establish some form of rural CMS on a pilot basis, during the 1990s (Carrin et al., 1999; Wagstaff and Yu, 2007). In 2003 a nationwide project known as the New Cooperative Medical Scheme (NCMS) was implemented in rural China. It is a voluntary health insurance program with huge government subsidies, and aims at covering all rural population by the end of 2010 . Wagstaff et al. (2009) show that NCMS has increased both outpatient and inpatient utilization by $20-30 \%$ for rural households, including rural children. Lei and Lin (2009) find that the NCMS has significantly improved the utilization of preventive care in rural areas. In contrast, China's urban health insurance system was mainly consisted of labor insurance schemes (LIS) and government employee insurance scheme (GIS) before 1998, and children were treated as dependents eligible for partial coverage (Liu, 2002). In 1998, the government launched a health reform in urban china, aiming at merging the dual system of GIS and LIS into a new insurance scheme known as Urban Employee Basic Health Insurance Scheme (BHIS) (Xu et al., 2007). However, in most areas, dependent children of the insured, who used to be partially covered by LIS, were excluded from this new health insurance system. Therefore, there were more improvements in child health insurance coverage in rural areas than in urban areas during the study period 1989-2006, and as shown in our results, rural children have better access and use of preventive services essential for child health and nutritional status than before.

Access to preventive health services, including preventive check-up and immunization, is expected to improve child nutritional status by reducing the incidence and severity of illness (Alderman and Garcia, 1994; Behrman and Skoufias, 2004; Bredenkamp, 2009). Childhood disease may lead to decreased dietary intake, poor absorption of nutrients or increased calorie needs to combat disease, and result in rapid depletion of nutritional stores and consequently growth faltering, particularly for younger children (Scrimshaw \& SanGiovanni, 1997; Weisz et al., 2011; Rodríguez et al., 2011). 
One more explanation is that the one child policy has been enforced better in rural areas in the recent years, so rural households have fewer children than before, which may lead to better nutrition status of rural children (Bredenkamp, 2009). Household with fewer children may have more household resources and time allocated towards enhancing child nutritional status. Pregnant women expecting fewer children in their life may be more likely to take appropriate antenatal care and advice, and have better birth outcomes (Guilkey et al., 1989), which, in turn, improve child nutritional status later in life. Bredenkamp (2009) find that the status of only one child in the household is significantly associated with better nutritional status for children in China.

Our decomposition results suggest that demographic characteristics, health insurance, parents' socioeconomic factors, and health behaviors account for about half of the observed differences in health and nutritional status between urban and rural children. This highlights the potential importance of other, unobserved factors in explaining half of the remaining differences. Identifying the causes of these urban-rural health and nutritional disparities and developing appropriate policy recommendations are future directions for researchers and policymakers.

\section{Acknowledgements}

The authors are grateful to the editor, Dr. John Komlos, and the anonymous referees for their helpful comments on earlier versions of the paper. Funding supports for this study are from the Natural Science Foundation of China (NSFC) (71173227), and the Humanities and Social Science Foundation of China's Ministry of Education (09YJC790274). The authors are responsible for any errors. 


\section{References}

Abassi, V., 1998. Growth and normal puberty. Pediatrics 102 (S2), 507-511.

Abdeen, Z., Greenough, P.G., Chandran, A., Qasrawi, R., 2007. Assessment of the nutritional status of preschool-age children during the second Intifada in Palestine. Food and Nutrition Bulletin 28(3), 274-282.

Agency for Healthcare Research and Quality, 2005. Fact sheet: health care disparities in rural areas. AHRQ Publication No. 05-P022.

Alderman, H., Garcia, M., 1994. Food security and health security: explaining the levels of nutrition in Pakistan. Economic Development and Cultural Change 42(3), 485-507.

Alderman, H., Hoddinott, J., Kinsey, B., 2003. Long-term consequences of early childhood malnutrition. FCND Discussion Paper 168. Washington, DC, USA: Food Consumption and Nutrition Division, International Food Policy Research Institute.

Anderson, M.A., 1979. Comparison of anthropometric measures of nutritional status in preschool children in five developing countries. The American Journal of Clinical Nutrition 32, 2339-2345.

Behrman, J.R., Skoufias, E., 2004. Correlates and determinants of child anthropometrics in Latin America: background and overview of the symposium. Economics and Human Biology 2(3), 335-351.

Black, R. E., Morris, S. S., Bryce, J., 2003. Where and why are 10 million children dying every year? Lancet 361, 2226-2234.

Blinder, A. S., 1973. Wage discrimination: reduced form and structural estimates. Journal of Human Resources 8, 436-455.

Bredenkamp, C., 2009. Policy-related determinants of child nutritional status in China: the effect of only-child status and access to healthcare. Social Science and Medicine 69, 1531-1538.

Carrin, G., Ron, A., Yang, H., Wang, H., Zhang, T., Zhang, L., Zhang, S., Ye, Y., Chen, J., Jiang, Q., Zhang, Z., Yu, J., Li, X., 1999. The reform of the rural cooperative medical system in the People's Republic of China: interim experience in 14 pilot 
counties. Social Science and Medicine 48, 961-972.

Case, A., Lubotsky, D., Paxson, C., 2002. Economic status and health in childhood: the origins of the gradient, American Economic Review 92(5), 1308-1334.

Chang, Y., Zhai, F., Li, W., Ge, K., Jin, D., de Onis, M., 1994. Nutritional status of preschool children in poor rural areas of China. Bulletin of the World Health Organization 72(1), 105-112.

Chen, C., 2000. Fat intake and nutritional status of children in China. The American Journal of Clinical Nutrition 72(5 Suppl.), 1368S-1372S.

Chen, Y., Li, H., 2009. Mother's education and child health: is there a nurturing effect? Journal of Health Economics 28(2), 413-426.

CHNS, 2012. Weights for the China Health and Nutrition Study. http://www.cpc.unc.edu/projects/china/data/datasets/data_downloads/longitudinal/ weights-chns.pdf/view (Accessed on 01/17/2012).

Cordeiro, L.S., Lamstein, S., Mahmud, Z., and Levinson, F.J. 2005. Adolescent malnutrition in developing countries: a close look at the problem and at two national experiences. United Nations SCN News: Developments in International Nutrition, 31, late 2005-early 2006, 6-13.

Currie, J., Stabile, M., 2003. Socioeconomic status and child health: why is the relationship stronger for older children? American Economic Review 93(5), $1813-1823$.

Dearth-Wesley, T., Wang, H., Popkin, B.M., 2008. Under- and overnutrition dynamics in Chinese children and adults (1991-2004). European Journal of Clinical Nutrition 62, 1302-1307.

Delisle, H., Chandra-Mouli, V., de Benoist, B., 2001. Should adolescents be specifically targeted for nutrition in developing countries? to address which problems, and how? http://www.who.int/child-adolescent-health/New_Publications/NUTRITION/Ado lescent_nutrition_paper.pdf. [last accessed on 2005 Jul 10].

Dong, K., 2009. Medical insurance system evolution in China. China Economic Review 20(4), 591-597. 
Du, S., Lu, B., Zhai, F., Popkin, B.M., 2002. A new stage of the nutrition transition in China. Public Health Nutrition 5(1A), 169-174.

Fang, H., Chen, J., Rizzo, J.A., 2009a. Explaining Urban-Rural Health Disparities in China. Medical Care 47(12), 1209-1216.

Fang, H., Ali, M.M., Rizzo, J.A., 2009b. Does smoking affect body weight and obesity in China? Economics and Human Biology 7(3): 334-350.

Fairlie, R., 2005. An extension of the Blinder-Oaxaca decomposition technique to logit and probit models. Journal of Economic and Social Measurement 10, $305-316$.

Guilkey, D.K., Popkin, B.M., Akin, J.S., Wong, E.L., 1989. Prenatal care and pregnancy outcome in Cebu, Philippines. Journal of Development Economics 30, $241-272$.

Guo, X., Mroz, T.A., Popkin, B.M., Zhai, F., 2000. Structural changes in the impact of income on food consumption in China, 1989-1993. Economic Development and Cultural Change 48, 737-760.

Heald, F.P., Gong, E.J., 1999. Diet, nutrition, and adolescence. In Shils, M.E., Olson, J.A., Shike, M., Ross, A.C. (Eds.). Modern Nutrition in Health and Disease. Ninth Edition. Williams and Wilkins: Maryland, USA, pp. 857-867.

Hesketh, T., Ding, Q.J., Tomkins, A.M., 2003. Health and health care-seeking behavior of adolescents in urban and rural China. Journal of Adolescent Health 33(4), $271-274$.

Hoddinott, J., Maluccio, J.A., Behrman, J.R., Flores, R., Martorell, R., 2008. Effect of a nutrition intervention during early childhood on economic productivity in guatemalan adults. Lancet 371, 411-416.

Hsiao, W.C., Liu, Y., 1996. Economic reform and health - lessons from China. The New England Journal of Medicine 335(6), 430-432.

Jamison, D.T., 1986. Child malnutrition and school performance in China. Journal of Development Economics 20(2), 229-309.

Jones, F.L., 1983. On decomposing the wage gap: a critical comment on Blinder's method. The Journal of Human Resources 18, 126-130. 
Jones-Smith, J., Popkin, B.M., 2010. Understanding community context and adult health changes in China: development of an urbanicity scale. Social Science and Medicine 71, 1436-1446.

Kurz,K.M., Johnson-Welch, C., 1994. The nutrition and lives of adolescents in developing countries: Findings from the nutrition of adolescent girls research program. ICRW.

Lei, X.Y., Lin, W.C., 2009. The new cooperative medical scheme in rural China: Does more coverage mean more service and better health? Health Economics 18(S2), S25-S46.

Li, Y.P., Hu, X.Q., Jing-Zhao, Yang, X.G., Ma, G.S., 2009. Application of the WHO growth reference (2007) to assess the nutritional status of children in China. Biomedical and Environmental Sciences 22(2), 130-135.

Liu, Y., 2002. Reforming China's urban health insurance system. Health Policy 60(2), $133-150$.

Liu, Y., Hsiao, W.C., Eggleston, K., 1999. Equity in health and health care: the Chinese experience. Social Science and Medicine 49(10), 1349-1356.

Liu, Y., Hsiao, W.C., Li, Q., Liu, X., Ren, M., 1995. Transformation of China's rural health care financing. Social Science and Medicine 41(8), 1085-1093.

Luo, Y., Yang, F., Lei, S.F., Wang, X.L., Papasian, C.J., Deng, H.W., 2009. Differences of height and body mass index of youths in urban vs rural areas in Hunan province of China. Annals of Human Biology 36(6), 750-755.

Manary, M.J., Sandige, H.L., 2008. Management of acute moderate and severe childhood malnutrition. British Medical Journal 337, 1227-1230.

Ministry of Health, 2005. China health statistical yearbook 2005. Beijing: Peking Union Medical Press (in Chinese). http://www.moh.gov.cn/publicfiles/business/htmlfiles/zwgkzt/ptjnj/201010/49401 .htm.

Morgan, S.L., 2000. Richer and taller - stature and the standard of living in China, 1979-1995. The China Journal 44, 1-39.

Murasko, J.E., 2011. Associations between household income, height, and BMI in 
contemporary US schoolchildren. Economics and Human Biology, doi:10.1016/j.ehb.2011.09.001.

National Bureau of Statistics of China, 2000. China Population Census. Beijing: National Bureau of Statistics of China.

Neumark, D., 1988. Employers' discriminatory behavior and the estimation of wage discrimination. The Journal of Human Resources 23, 279-295.

Oaxaca, R.L., 1973. Male-female wage differentials in urban labor markets. International Economic Review 14, 693-709.

Oaxaca, R.L., Ransom, M.R., 1999. Identification in detailed wage decompositions. The Review of Economics and Statistics 81, 154-157.

Pong, R.W., DesMeules, M., Lagace, C., 2009. Rural-urban disparities in health: how does Canada fare and how does Canada compare with Australia? Australian Journal of Rural Health 17(1), 58-64.

Popkin, B.M., Du, S., 2003. Dynamics of the nutrition transition toward the animal foods sector in China and its implications: a worried perspective. Journal of Nutrition 133, 3898S-3906S.

Popkin, B.M., Du, S., Zhai, F., Zhang, B., 2010. Cohort profile: the China Health and Nutrition Survey--monitoring and understanding socio-economic and health change in China, 1989-2011. International Journal of Epidemiology 39(6),1435-1440.

Reimers, C.W., 1983. Labor market discrimination against Hispanic and black men. The Review of Economics and Statistics 65, 570-579.

Rice, A.L., Sacco, L., Hyder, A., Black, R.E., 2000. Malnutrition as an underlying cause of childhood deaths associated with infectious diseases in developing countries. Bulletin of the World Health Organization 78(10), 1207-1221.

Rodríguez, L., Cervantes, E., Ortiz, R., 2011. Malnutrition and gastrointestinal and respiratory infections in children: a public health problem. International Journal of Environmental Research and Public Health 8(4), 1174-1205.

Ruel, M.T., 2010. The oriente study: program and policy impacts. Journal of Nutrition $140,415-418$. 
Ruel, M.T., Menon, P., Habicht, J., Loechl, C., Bergeron, G., Pelto, G., Arimond, M., Maluccio, J., Michaud, L., Hankebo, B., 2008. Age-based preventive targeting of food assistance and behaviour change and communication for reduction of childhood undernutrition in Haiti: a cluster randomized trial. Lancet 371, 588-595.

Scrimshaw, N., SanGiovanni, J., 1997. Synergism of nutrition, infection, and immunity. American Journal of Clinical Nutrition 66, 464S-477S.

Shen, T., Habicht, J.P., Chang, Y., 1996. Effect of economic reforms on child growth in urban and rural areas of China. The New England Journal of Medicine 335(6), 400-406.

Smith, L.C., Ruel, M.T., Ndiaye, A., 2005. Why is child malnutrition lower in urban than in rural areas? Evidence from 36 developing countries. World Development 33(8), 1285-1305.

UN Millennium Project, 2005. Investing in development: A practical plan to achieve the millennium development goals. London, UK: United Nations Development Program.

http://www.unmillenniumproject.org/documents/MainReportComplete-lowres.pdf

US Census Bureau. Statistical Abstract of the United States. Texas: US Census Bureau; 2004-2005. Available at:

http://www.censusbureau.biz/prod/2004pubs/04statab/pop.pdf. Accessed February $26,2009$.

Van de Poel, E., O'Donnell, O., Van Doorslaer, E., 2007. Are urban children really healthier? Evidence from 47 developing countries. Social Science Medicine 65, 1986-2003.

Van de Poel, E., O’Donnell, O., Van Doorslaer, E., 2009. Urbanization and the spread of diseases of affluence in China. Economics and Human Biology 7(2), 200-216.

Victora, C.G., de Onis, M., Hallal, P.C., Blössner, M., Shrimpton, R., 2010. Worldwide timing of growth faltering: revisiting implications for interventions. Pediatrics 125, e 473 - e480. 
Wagstaff, A., Gao, J., Xu, L., Qian, J., Lindelow, M., 2009. Extending health insurance to the rural population: An impact evaluation of China's new cooperative medical scheme. Journal of Health Economics 28, 1-19.

Wagstaff, .A, Yu, S., 2007. Do health sector reforms have their intended impacts? The World Bank's health VIII project in Gansu province, China. Journal of Health Economics 26(3), 505-535.

Wang, Y., Bentley, M.E., Zhai, F., Popkin, B.M., 2002. Tracking of dietary intake patterns of Chinese from childhood to adolescence over a six-year follow-up period. The Journal of Nutrition132(3):430-438.

Weisz, A., Meuli, G., Thakwalakwa, C., Trehan, I., Maleta, K., Manary, M., 2011. The duration of diarrhea and fever is associated with growth faltering in rural Malawian children aged 6-18 months. Nutrition Journal 10(1), 25.

Xu, L., Wang, Y., Collins, C.D., Tang, S., 2007. Urban health insurance reform and coverage in China using data from National Health Services Surveys in 1998 and 2003. BMC Health Service Research 7, 37.

Yang, J., 2007. China's one-child policy and overweight children in the 1990s. Social Science and Medicine 64, 2043-2057.

Yun, M.-S., 2005. A simple solution to the identification problem in detailed wage decompositions. Economic Inquiry 43, 766-772.

Zhang, Q., Zou, H., 2012. Regional inequality in contemporary China. Annals of Economics and Finance 13-1, 119-143. 

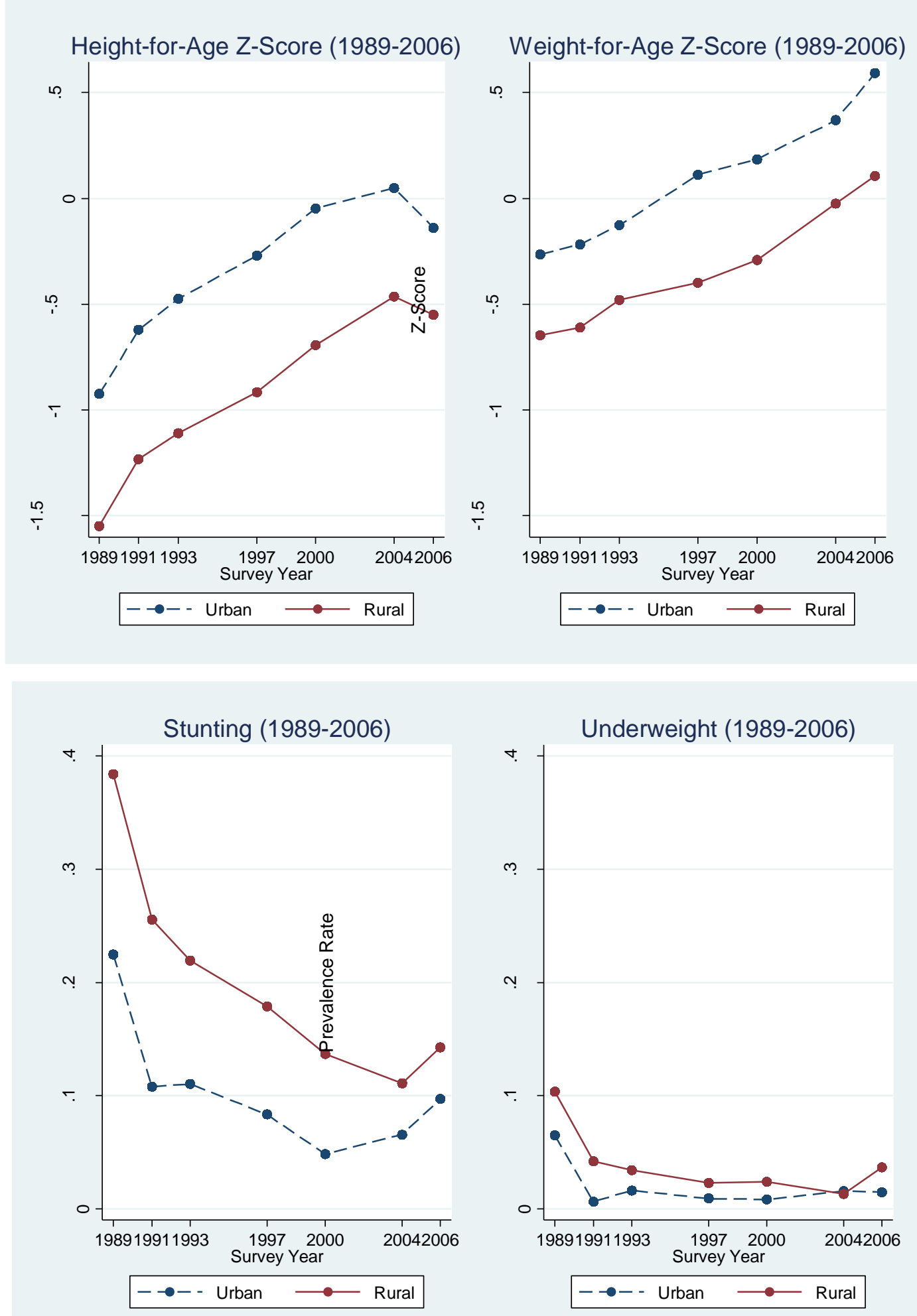

Fig. 1. Time trends of child health and nutrition status in urban and rural China. Note: Based upon CHNS data (1989, 1991, 1993, 1997, 2000, 2004 and 2006). 
Table 1

Descriptive Statistics

\begin{tabular}{|c|c|c|c|c|c|}
\hline \multirow{3}{*}{$\begin{array}{l}\text { Sample Size } \\
\text { Variable }\end{array}$} & \multirow{2}{*}{\multicolumn{2}{|c|}{$\begin{array}{c}\text { All } \\
15,719\end{array}$}} & \multirow{3}{*}{$\begin{array}{l}\text { Urban } \\
3,724 \\
\text { Mean } \\
\end{array}$} & \multirow{3}{*}{$\begin{array}{c}\text { Rural } \\
11,995 \\
\text { Mean } \\
\end{array}$} & \multirow[b]{3}{*}{$\mathrm{P}^{*}$} \\
\hline & & & & & \\
\hline & Mean & Std. Dev. & & & \\
\hline \multicolumn{6}{|l|}{ Health and nutritional status } \\
\hline Height-for-age $z$-score & -0.79 & 1.37 & -0.33 & -0.93 & $<0.001$ \\
\hline Weight-for-age $z$-score & -0.26 & 1.21 & 0.07 & -0.36 & $<0.001$ \\
\hline Stunted & 0.17 & 0.38 & 0.09 & 0.19 & $<0.001$ \\
\hline Underweight & 0.03 & 0.17 & 0.01 & 0.03 & $<0.001$ \\
\hline \multicolumn{6}{|l|}{ Child daily food consumption } \\
\hline Cereals $(\mathrm{g})$ & 1808.05 & 840.81 & 1508.06 & 1917.25 & $<0.001$ \\
\hline Meat and Poultry (g) & 385.54 & 305.80 & 432.43 & 367.36 & $<0.001$ \\
\hline Eggs (g) & 146.01 & 115.68 & 151.23 & 144.78 & 0.027 \\
\hline Preventive health care use & 0.05 & 0.21 & 0.07 & 0.04 & $<0.001$ \\
\hline \multicolumn{6}{|l|}{ Control variables } \\
\hline Health insurance & 0.19 & 0.39 & 0.24 & 0.18 & $<0.001$ \\
\hline Child age & & & & & 0.005 \\
\hline $0-5$ & 0.17 & 0.38 & 0.16 & 0.18 & \\
\hline $6-11$ & 0.42 & 0.49 & 0.42 & 0.43 & \\
\hline $12-17$ & 0.40 & 0.49 & 0.42 & 0.40 & \\
\hline Girl & 0.47 & 0.50 & 0.47 & 0.47 & 0.503 \\
\hline Han & 0.84 & 0.36 & 0.90 & 0.83 & $<0.001$ \\
\hline Student & 0.67 & 0.47 & 0.72 & 0.66 & $<0.001$ \\
\hline $\begin{array}{l}\text { Household income per capita } \\
\text { (1000RMB in } 2006 \text { value) }\end{array}$ & 4.05 & 4.64 & 3.87 & 4.62 & $<0.001$ \\
\hline Household head is male & 0.82 & 0.38 & 0.76 & 0.85 & $<0.001$ \\
\hline Household size & 4.53 & 1.31 & 4.11 & 4.66 & $<0.001$ \\
\hline Mother's age & 37.28 & 6.33 & 37.69 & 37.16 & $<0.001$ \\
\hline Mother's height & 155.44 & 5.88 & 156.99 & 154.97 & $<0.001$ \\
\hline Mother's BMI & 22.39 & 3.40 & 22.72 & 22.30 & $<0.001$ \\
\hline Mother's education & & & & & $<0.001$ \\
\hline$<$ primary school & 0.29 & 0.45 & 0.12 & 0.34 & \\
\hline Primary school & 0.23 & 0.42 & 0.15 & 0.26 & \\
\hline Lower middle school & 0.31 & 0.46 & 0.35 & 0.30 & \\
\hline Upper middle school & 0.15 & 0.35 & 0.32 & 0.10 & \\
\hline College & 0.02 & 0.13 & 0.06 & 0.00 & \\
\hline Mother employed & 0.85 & 0.35 & 0.79 & 0.88 & $<0.001$ \\
\hline Mother smokes & 0.02 & 0.14 & 0.01 & 0.02 & $<0.001$ \\
\hline Mother drinks & 0.11 & 0.31 & 0.12 & 0.11 & 0.016 \\
\hline Presence of mother & 0.89 & 0.31 & 0.87 & 0.91 & $<0.001$ \\
\hline Father's age & 38.92 & 6.81 & 39.80 & 38.67 & $<0.001$ \\
\hline Father's height & 165.94 & 6.44 & 167.71 & 165.41 & $<0.001$ \\
\hline Father's BMI & 22.33 & 3.09 & 23.25 & 22.04 & $<0.001$ \\
\hline Father's education & & & & & $<0.001$ \\
\hline$<$ primary school & 0.11 & 0.32 & 0.06 & 0.13 & \\
\hline Primary school & 0.24 & 0.43 & 0.12 & 0.27 & \\
\hline Lower middle school & 0.41 & 0.49 & 0.35 & 0.43 & \\
\hline Upper middle school & 0.21 & 0.41 & 0.35 & 0.17 & \\
\hline
\end{tabular}




\begin{tabular}{llllll}
\hline \multicolumn{1}{c}{ College } & 0.03 & 0.17 & 0.11 & 0.01 & \\
Father employed & 0.93 & 0.26 & 0.91 & 0.94 & $<0.001$ \\
Father smokes & 0.68 & 0.47 & 0.65 & 0.68 & 0.002 \\
Father drinks & 0.63 & 0.48 & 0.66 & 0.62 & $<0.001$ \\
Presence of father & 0.87 & 0.34 & 0.84 & 0.89 & $<0.001$ \\
Province & & & & & $<0.001$ \\
$\quad$ Liaoning & 0.08 & 0.28 & 0.09 & 0.07 & \\
$\quad$ Heilongjiang & 0.06 & 0.24 & 0.06 & 0.06 & \\
Jiangsu & 0.09 & 0.29 & 0.10 & 0.09 & \\
Shandong & 0.09 & 0.29 & 0.11 & 0.08 & \\
Henan & 0.12 & 0.32 & 0.13 & 0.11 & \\
Hubei & 0.13 & 0.34 & 0.11 & 0.14 & \\
Hunan & 0.12 & 0.33 & 0.14 & 0.12 & \\
Guangxi & 0.14 & 0.35 & 0.13 & 0.15 & \\
Guizhou & 0.16 & 0.37 & 0.15 & 0.17 & \\
Wave & & & & & 0.079 \\
1989 & 0.04 & 0.19 & 0.04 & 0.05 & \\
1991 & 0.21 & 0.41 & 0.21 & 0.21 & \\
1993 & 0.21 & 0.41 & 0.20 & 0.21 & \\
1997 & 0.18 & 0.38 & 0.18 & 0.18 & \\
2000 & 0.16 & 0.37 & 0.16 & 0.16 & \\
2004 & 0.10 & 0.30 & 0.10 & 0.10 & \\
2006 & 0.11 & 0.31 & 0.11 & 0.11 & \\
\hline
\end{tabular}

Source: Authors' calculations from the China and Health Nutrition Survey data 1989-2006.

Notes: ${ }^{*} \chi^{2}$ test for category variables and $t$-test for continuous variables. 


\section{Table 2}

Multivariate Analyses of Child Health Status Using Pooled CHNS Data 1989-2006

\begin{tabular}{|c|c|c|c|c|}
\hline & \multicolumn{2}{|c|}{ OLS Regression } & \multicolumn{2}{|c|}{ Logistic Regression } \\
\hline & $\begin{array}{c}\text { Height-for-Age } \\
\text { Z Score }\end{array}$ & $\begin{array}{c}\text { Weight-for-Age } \\
\text { Z Score }\end{array}$ & Stunted & Underweight \\
\hline & Coef. & Coef. & Odds Ratio & Odds Ratio \\
\hline \multirow[t]{2}{*}{ Urban } & $0.29 * * *$ & $0.19 * * *$ & $0.62 * * *$ & $0.62 * *$ \\
\hline & $(0.04)$ & $(0.03)$ & $(0.06)$ & $(0.12)$ \\
\hline \multirow[t]{2}{*}{ Health insurance } & $0.20 * * *$ & $0.07 * *$ & $0.69 * * *$ & 0.81 \\
\hline & $(0.03)$ & $(0.03)$ & $(0.06)$ & $(0.15)$ \\
\hline \multirow[t]{2}{*}{ Child age: $6-11$} & $0.18^{* * *}$ & $-0.10 * * *$ & $0.72 * * *$ & $0.42 * * *$ \\
\hline & $(0.05)$ & $(0.04)$ & $(0.06)$ & $(0.08)$ \\
\hline \multirow[t]{2}{*}{ Child age: $12-17$} & $0.19^{* * *}$ & $-0.25 * * *$ & $0.65 * * *$ & $0.65^{* *}$ \\
\hline & $(0.05)$ & $(0.05)$ & $(0.07)$ & $(0.13)$ \\
\hline \multirow[t]{2}{*}{ Girl } & 0.04 & 0.03 & 0.91 & 1.17 \\
\hline & $(0.03)$ & $(0.02)$ & $(0.06)$ & $(0.14)$ \\
\hline \multirow[t]{2}{*}{ Han } & 0.00 & -0.01 & 0.89 & 0.76 \\
\hline & $(0.05)$ & $(0.04)$ & $(0.09)$ & $(0.14)$ \\
\hline \multirow[t]{2}{*}{ Student } & $0.05^{*}$ & $-0.05 *$ & $0.88^{*}$ & $0.69 * *$ \\
\hline & $(0.03)$ & $(0.03)$ & $(0.06)$ & $(0.11)$ \\
\hline \multirow{2}{*}{ Log(HH income per capita) } & $0.07 * * *$ & $0.03 *$ & $0.92 * * *$ & 0.98 \\
\hline & $(0.01)$ & $(0.01)$ & $(0.03)$ & $(0.08)$ \\
\hline \multirow[t]{2}{*}{ Household head is male } & $-0.17 * * *$ & $-0.13 * *$ & $1.41 *$ & 0.90 \\
\hline & $(0.06)$ & $(0.06)$ & $(0.25)$ & $(0.30)$ \\
\hline \multirow[t]{2}{*}{ Household size } & -0.02 & -0.01 & 1.00 & 1.06 \\
\hline & $(0.01)$ & $(0.01)$ & $(0.02)$ & $(0.04)$ \\
\hline \multirow[t]{2}{*}{ Mother's age } & $0.01 *$ & 0.00 & $0.97 * * *$ & $0.94 * * *$ \\
\hline & $(0.01)$ & $(0.00)$ & $(0.01)$ & $(0.02)$ \\
\hline \multirow[t]{2}{*}{ Mother's height } & $0.04 * * *$ & $0.02 * * *$ & $0.94 * * *$ & $0.94 * * *$ \\
\hline & $(0.00)$ & $(0.00)$ & $(0.01)$ & $(0.01)$ \\
\hline \multirow[t]{2}{*}{ Mother's BMI } & $0.03 * * *$ & $0.04 * * *$ & $0.93 * * *$ & $0.89 * * *$ \\
\hline & $(0.00)$ & $(0.01)$ & $(0.01)$ & $(0.03)$ \\
\hline \multirow[t]{2}{*}{ Mother_edu: primary school } & 0.02 & -0.05 & 0.95 & 0.80 \\
\hline & $(0.04)$ & $(0.04)$ & $(0.09)$ & $(0.15)$ \\
\hline \multirow[t]{2}{*}{ Mother_edu: middle school } & 0.05 & -0.00 & 0.86 & 0.90 \\
\hline & $(0.05)$ & $(0.04)$ & $(0.09)$ & $(0.18)$ \\
\hline \multirow[t]{2}{*}{ Mother_edu: high school } & $0.14 * *$ & 0.07 & $0.73 * *$ & 1.14 \\
\hline & $(0.06)$ & $(0.05)$ & $(0.11)$ & $(0.31)$ \\
\hline \multirow[t]{2}{*}{ Mother_edu: college } & -0.05 & 0.01 & 1.32 & \\
\hline & $(0.11)$ & $(0.12)$ & $(0.48)$ & \\
\hline Mother employed & -0.01 & 0.02 & 1.02 & 1.36 \\
\hline & $(0.04)$ & $(0.04)$ & $(0.12)$ & $(0.31)$ \\
\hline Mother smokes & -0.11 & -0.07 & 0.96 & 1.25 \\
\hline & $(0.09)$ & $(0.07)$ & $(0.22)$ & $(0.64)$ \\
\hline Mother drinks & 0.02 & 0.04 & 0.87 & $0.57 * *$ \\
\hline & $(0.04)$ & $(0.03)$ & $(0.09)$ & $(0.13)$ \\
\hline Father's age & $0.01 * *$ & 0.00 & 0.99 & 1.00 \\
\hline & $(0.00)$ & $(0.00)$ & $(0.01)$ & $(0.02)$ \\
\hline Father's height & $0.04 * * *$ & $0.02 * * *$ & $0.95 * * *$ & $0.97 * *$ \\
\hline & $(0.00)$ & $(0.00)$ & $(0.01)$ & $(0.01)$ \\
\hline Father's BMI & $0.02 * * *$ & $0.05^{* * *}$ & 0.98 & $0.92 * *$ \\
\hline & $(0.01)$ & $(0.01)$ & $(0.01)$ & $(0.04)$ \\
\hline Father_edu:primary school & $0.13 * *$ & -0.01 & $0.72 * * *$ & 1.20 \\
\hline & $(0.06)$ & $(0.04)$ & $(0.08)$ & $(0.29)$ \\
\hline Father_edu: middle school & $0.18 * * *$ & -0.02 & $0.64 * * *$ & 1.19 \\
\hline & $(0.06)$ & $(0.04)$ & $(0.07)$ & $(0.26)$ \\
\hline Father_edu: high school & $0.18 * * *$ & 0.01 & $0.65^{* * *}$ & 0.93 \\
\hline
\end{tabular}




\begin{tabular}{lcccc} 
& $(0.06)$ & $(0.05)$ & $(0.09)$ & $(0.28)$ \\
Father_edu: college & $0.48^{* * *}$ & $0.27^{* *}$ & $0.24 * * *$ & 1.21 \\
& $(0.10)$ & $(0.11)$ & $(0.10)$ & $(0.94)$ \\
Father employed & -0.05 & $-0.12^{* *}$ & 0.85 & 0.83 \\
& $(0.07)$ & $(0.06)$ & $(0.12)$ & $(0.27)$ \\
Father smokes & $0.05^{*}$ & $0.07 * * *$ & 0.89 & 0.82 \\
& $(0.03)$ & $(0.03)$ & $(0.06)$ & $(0.12)$ \\
Father drinks & -0.03 & -0.03 & 1.07 & 1.04 \\
& $(0.03)$ & $(0.02)$ & $(0.07)$ & $(0.16)$ \\
Waves 1997-2000 & $0.20^{* * *}$ & $0.15^{* * *}$ & $0.74^{* * *}$ & $0.61^{* * *}$ \\
& $(0.03)$ & $(0.02)$ & $(0.05)$ & $(0.09)$ \\
Waves 2004-2006 & $0.30^{* * * *}$ & $0.40^{* * *}$ & $0.73^{* * *}$ & 0.91 \\
& $(0.04)$ & $(0.04)$ & $0.07)$ & $(0.16)$ \\
\hline Observations & 13011 & 13011 & 13011 & 12790 \\
(Pseudo) $R^{2}$ & 0.25 & 0.22 & 0.14 & 0.16 \\
\hline
\end{tabular}

Source: Authors' calculations from the China and Health Nutrition Survey data 1989-2006.

Notes: (i) $* p<0.10, * * p<0.05, * * * p<0.01$. (ii) Cluster-robust standard errors are reported in parenthesis. (iii) Other covariates include indicators of provinces, indicators for whether mother or father is missing in the health survey, and a constant (for continuous dependent variables), which are not reported here. 


\section{Table 3}

Blinder-Oaxaca Decomposition Results between Urban Children and Rural Children

\begin{tabular}{lcccc}
\hline & \multicolumn{2}{c}{ OLS Regression } & \multicolumn{2}{c}{ Logistic Regression } \\
\cline { 2 - 5 } & $\begin{array}{c}\text { Height-for-Age } \\
\text { Z Score }\end{array}$ & $\begin{array}{c}\text { Weight-for-Age } \\
\text { Z Score }\end{array}$ & Stunted & Underweight \\
\hline Predicted value & & & & \\
Rural children & $-0.93^{* * *}$ & $-0.35^{* * *}$ & $19.67 \% * * *$ & $3.26 \% * * *$ \\
& $(0.01)$ & $(0.01)$ & $(0.0040)$ & $(0.0018)$ \\
Urban children & $-0.31^{* * *}$ & $0.09^{* * *}$ & $9.38 \% * * *$ & $1.60 \% * * *$ \\
& $(0.02)$ & $(0.02)$ & $(0.0052)$ & $(0.0024)$ \\
Difference in predicted value & & & & \\
Total difference (rural-urban) & $-0.62^{* * *}$ & $-0.44^{* * *}$ & $10.29 \% * * *$ & $1.67 \% * * *$ \\
Explained difference & $(0.03)$ & $(0.03)$ & $(0.0066)$ & $(0.0030)$ \\
& $-0.33^{* * *}$ & $-0.25^{* * *}$ & $5.87 \% * * *$ & $0.92 \% * * *$ \\
Unexplained difference & $(0.02)$ & $(0.02)$ & $(0.0042)$ & $(0.0017)$ \\
& $-0.29^{* * *}$ & $-0.19^{* * *}$ & $4.42 \% * * *$ & $0.75 \% * *$ \\
\hline
\end{tabular}

Notes: (i) $* p<0.10, * * p<0.05, * * * p<0.01$. (ii) Robust standard errors are reported in parenthesis. 


\section{Table 4}

Multivariate Analyses of the Trend of Child Health Status from 1989 to 2006

\begin{tabular}{|c|c|c|c|c|}
\hline & \multicolumn{4}{|c|}{ Child Health and Nutritional Status } \\
\hline & $\begin{array}{l}\text { Height-for-Age } \\
\text { Z Score }\end{array}$ & $\begin{array}{l}\text { Weight-for-Age } \\
\text { Z Score }\end{array}$ & Stunted & Underweight \\
\hline Panel 1. & \multicolumn{4}{|c|}{$\begin{array}{c}\text { Multivariate Analyses with Interaction Terms between URBAN Dummy } \\
\text { and Time Periods'Dummies }\end{array}$} \\
\hline & Coef. & Coef. & Odds Ratio & Odds Ratio \\
\hline Urban & $\begin{array}{l}0.33 * * * \\
(0.05)\end{array}$ & $\begin{array}{l}0.15 * * * \\
(0.04)\end{array}$ & $\begin{array}{l}0.60 * * * \\
(0.08)\end{array}$ & $\begin{array}{l}0.55 * * * \\
(0.13)\end{array}$ \\
\hline Urban×Waves 1997-2000 & $\begin{array}{l}-0.01 \\
(0.06)\end{array}$ & $\begin{array}{l}0.06 \\
(0.06)\end{array}$ & $\begin{array}{l}0.88 \\
(0.15)\end{array}$ & $\begin{array}{l}1.06 \\
(0.47)\end{array}$ \\
\hline Urban×Waves 2004-2006 & $\begin{array}{l}-0.17 * * \\
(0.08)\end{array}$ & $\begin{array}{c}0.10 \\
(0.08)\end{array}$ & $\begin{array}{l}1.44 * \\
(0.31)\end{array}$ & $\begin{array}{c}1.76 \\
(0.78)\end{array}$ \\
\hline Waves 1989-1993 & \multicolumn{4}{|c|}{ Reference } \\
\hline Waves 1997-2000 & $\begin{array}{l}0.20 * * * \\
(0.03)\end{array}$ & $\begin{array}{l}0.13 * * * \\
(0.03)\end{array}$ & $\begin{array}{l}0.75 * * * \\
(0.05)\end{array}$ & $\begin{array}{l}0.61 * * * \\
(0.10)\end{array}$ \\
\hline Waves 2004-2006 & $\begin{array}{l}0.34 * * * \\
(0.04)\end{array}$ & $\begin{array}{l}0.38 * * * \\
(0.04)\end{array}$ & $\begin{array}{l}0.69 * * * \\
(0.07)\end{array}$ & $\begin{array}{c}0.84 \\
(0.16) \\
\end{array}$ \\
\hline $\begin{array}{l}\text { Observations } \\
\text { (Pseudo) } R^{2}\end{array}$ & $\begin{array}{c}13011 \\
0.25\end{array}$ & $\begin{array}{c}13011 \\
0.22\end{array}$ & $\begin{array}{c}13011 \\
0.14\end{array}$ & $\begin{array}{c}12790 \\
0.16\end{array}$ \\
\hline
\end{tabular}

Panel 2.

Multivariate Analyses Separately for Three Periods

\begin{tabular}{ccccc}
\hline & $\begin{array}{c}\text { Coef. of } \\
\text { Urban }\end{array}$ & $\begin{array}{c}\text { Coef. of } \\
\text { Urban }\end{array}$ & $\begin{array}{c}\text { Odds Ratio of } \\
\text { Urban }\end{array}$ & $\begin{array}{c}\text { Odds Ratio of } \\
\text { Urban }\end{array}$ \\
\hline Waves & & & & \\
$1989-1993$ & $0.35^{* * *}$ & $0.19^{* * *}$ & $0.59^{* * *}$ & $0.54^{* * *}$ \\
& $(0.05)$ & $(0.04)$ & $(0.08)$ & $(0.13)$ \\
$1997-2000$ & $0.26^{* * *}$ & $0.18^{* * *}$ & $0.63^{* * *}$ & 0.73 \\
& $(0.06)$ & $(0.05)$ & $(0.11)$ & $(0.35)$ \\
$2004-2006$ & 0.09 & $0.13^{*}$ & 0.84 & 1.16 \\
& $(0.08)$ & $(0.08)$ & $(0.17)$ & $(0.50)$ \\
\hline
\end{tabular}

Notes: (i) $* p<0.10, * * p<0.05, * * * p<0.01$. (ii) Cluster-robust standard errors are reported in parenthesis. (iii) Each cell in Panel 2 represents a cross-sectional regression, and we only report the coefficients of URBAN dummy here. (iv) Other control variables include child's characteristics as age, gender, nationality, and student status; household characteristics as household income, gender of household head, and household size; mother's characteristics if present in the survey, such as mother's age, height, BMI, education, employment status, smoking and drinking behavior, and an indicator for the presence of mother in the survey; father's characteristics if present in the survey, such as father's age, height, BMI, education, employment status, smoking and drinking behavior, and an indicator for the presence of father in the survey; indicators of provinces; and a constant (for continuous dependent variables), which are not reported here. 


\section{Table 5}

Multivariate Analyses of the Trend of Child Health Status for Boys and Girls (1989-2006)

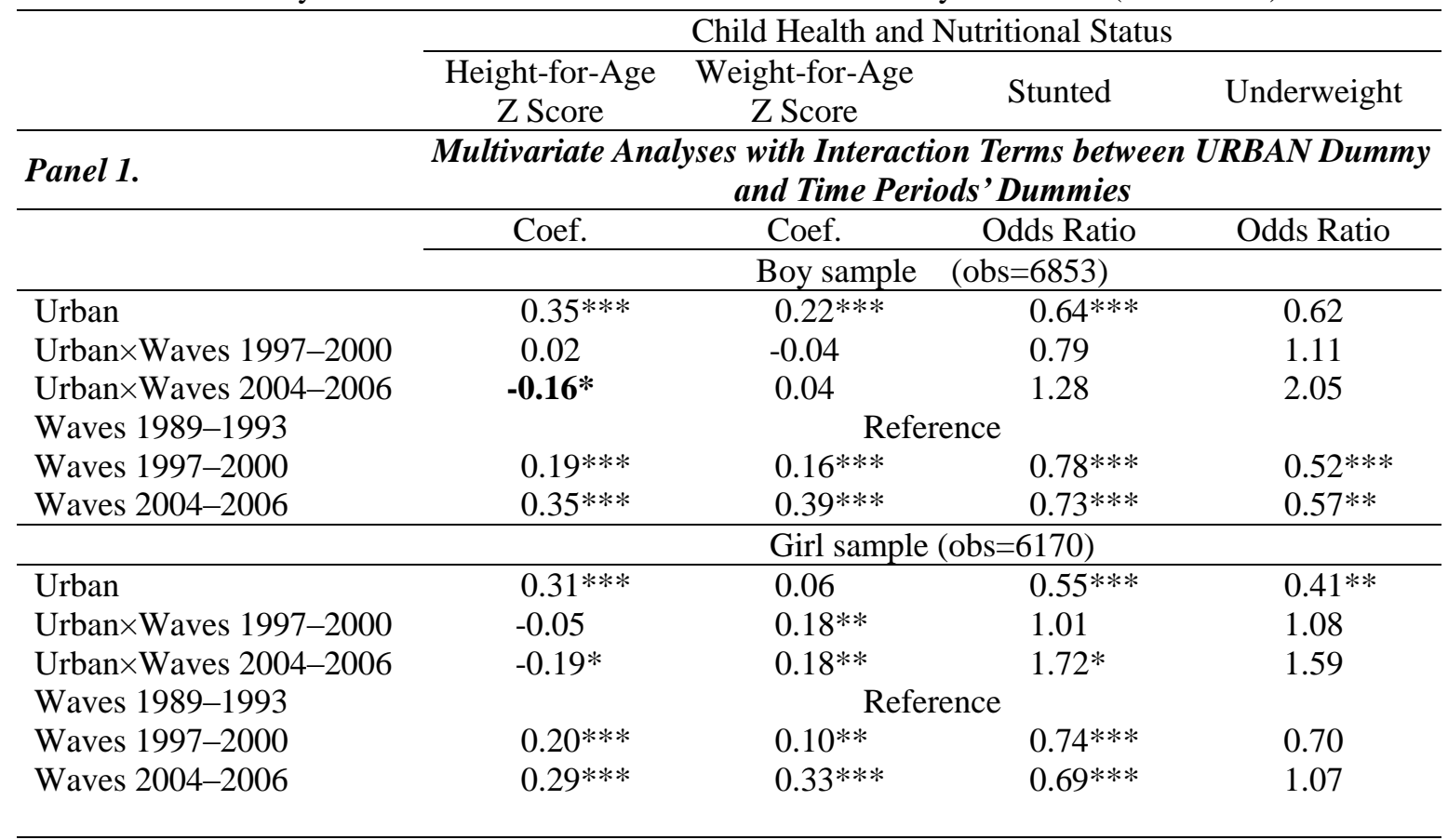

Panel 2.

Multivariate Analyses Separately for Three Periods

\begin{tabular}{llllc}
\hline & $\begin{array}{c}\text { Coef. of } \\
\text { Urban }\end{array}$ & $\begin{array}{c}\text { Coef. of } \\
\text { Urban }\end{array}$ & $\begin{array}{c}\text { Odds Ratio of } \\
\text { Urban }\end{array}$ & $\begin{array}{c}\text { Odds Ratio of } \\
\text { Urban }\end{array}$ \\
\hline Waves & \multicolumn{4}{c}{ Boy sample } \\
$1989-1993$ & $0.35^{* * * *}$ & $0.26^{* * *}$ & $0.65^{* * *}$ & 0.64 \\
$1997-2000$ & $0.34^{* * *}$ & $0.18^{* * *}$ & $0.55^{* * *}$ & 0.82 \\
$2004-2006$ & 0.09 & 0.14 & 0.77 & 1.61 \\
\hline \multicolumn{5}{c}{ Girl sample } \\
\hline Waves & $0.33^{* * *}$ & $0.08^{*}$ & $0.51^{* * *}$ & $0.39^{* * *}$ \\
$1989-1993$ & $0.19^{* * *}$ & $0.17^{* * *}$ & 0.69 & 0.56 \\
$1997-2000$ & 0.08 & 0.16 & 0.89 & 0.93 \\
$2004-2006$ & &
\end{tabular}

Notes: (i) $* p<0.10, * * p<0.05, * * * p<0.01$. (ii) Cluster-robust standard errors are reported in parenthesis. (iii) Each cell in Panel 2 represents a cross-sectional regression, and we only report the coefficients of URBAN dummy here. (iv) Other control variables include child's characteristics as age, nationality, and student status; household characteristics as household income, gender of household head, and household size; mother's characteristics if present in the survey, such as mother's age, height, BMI, education, employment status, smoking and drinking behavior, and an indicator for the presence of mother in the survey; father's characteristics if present in the survey, such as father's age, height, BMI, education, employment status, smoking and drinking behavior, and an indicator for the presence of father in the survey; indicators of provinces; and a constant (for continuous dependent variables), which are not reported here. 
Table 6

Multivariate Analyses of Major Food-Groups Consumption and Preventive Health Care Use for Children from 1989 to 2006

\begin{tabular}{|c|c|c|c|c|}
\hline & \multicolumn{3}{|c|}{ Daily Consumption of Food Groups } & \multirow{2}{*}{$\begin{array}{l}\text { Preventive Health } \\
\text { Care Use }\end{array}$} \\
\hline & Log(Cereals) & Log(Meat\&Poultry) & Log(Eggs) & \\
\hline Panel 1. & \multicolumn{4}{|c|}{$\begin{array}{l}\text { Multivariate Analyses with Interaction Terms between URBAN Dummy } \\
\text { and Time Periods' Dummies }\end{array}$} \\
\hline & Coef. & Coef. & Coef. & Odds Ratio \\
\hline Urban & $\begin{array}{l}-0.12 * * * \\
(0.01)\end{array}$ & $\begin{array}{l}0.21 * * * \\
(0.04)\end{array}$ & $\begin{array}{l}0.06 \\
(0.05)\end{array}$ & $\begin{array}{l}2.43 * * * \\
(0.45)\end{array}$ \\
\hline Urban×Waves 1997-2000 & $\begin{array}{l}0.03 \\
(0.02)\end{array}$ & $\begin{array}{l}0.02 \\
(0.05)\end{array}$ & $\begin{array}{c}0.01 \\
(0.06)\end{array}$ & $\begin{array}{l}0.49 * * * \\
(0.12)\end{array}$ \\
\hline Urban×Waves 2004-2006 & $\begin{array}{l}0.09 * * * \\
(0.02)\end{array}$ & $\begin{array}{l}0.01 \\
(0.05)\end{array}$ & $\begin{array}{c}0.00 \\
(0.07)\end{array}$ & $\begin{array}{l}0.42 * * * \\
(0.11)\end{array}$ \\
\hline Waves 1989-1993 & \multicolumn{4}{|c|}{ Reference } \\
\hline Waves 1997-2000 & $\begin{array}{l}-0.10 * * * \\
(0.03)\end{array}$ & $\begin{array}{l}0.24 * * * \\
(0.08)\end{array}$ & $\begin{array}{l}0.56^{* * * *} \\
(0.11)\end{array}$ & $\begin{array}{l}1.83 * * * \\
(0.28)\end{array}$ \\
\hline Waves 2004-2006 & $\begin{array}{l}-0.23 * * * \\
(0.03)\end{array}$ & $\begin{array}{c}0.07 \\
(0.08)\end{array}$ & $\begin{array}{l}0.42 * * * \\
(0.11)\end{array}$ & $\begin{array}{l}1.80 * * * \\
(0.30)\end{array}$ \\
\hline $\begin{array}{l}\text { Observations } \\
\text { (Pseudo) } R^{2}\end{array}$ & $\begin{array}{c}12374 \\
0.52\end{array}$ & $\begin{array}{l}8176 \\
0.22\end{array}$ & $\begin{array}{l}5366 \\
0.08\end{array}$ & $\begin{array}{c}13011 \\
0.08\end{array}$ \\
\hline Panel 2. & \multicolumn{4}{|c|}{ Multivariate Analyses Separately for Three Periods } \\
\hline & $\begin{array}{l}\text { Coef. of } \\
\text { Urban }\end{array}$ & $\begin{array}{l}\text { Coef. of } \\
\text { Urban }\end{array}$ & $\begin{array}{l}\text { Coef. of } \\
\text { Urban }\end{array}$ & $\begin{array}{l}\text { Odds Ratio of } \\
\text { Urban }\end{array}$ \\
\hline Waves & & & & \\
\hline 1989-1993 & $\begin{array}{l}-0.12 * * * \\
(0.01)\end{array}$ & $\begin{array}{l}0.24 * * * \\
(0.04)\end{array}$ & $\begin{array}{l}0.09 * \\
(0.04)\end{array}$ & $\begin{array}{l}2.70 * * * \\
(0.53)\end{array}$ \\
\hline 1997-2000 & $\begin{array}{l}-0.10 * * * \\
(0.02)\end{array}$ & $\begin{array}{l}0.20 * * * \\
(0.04)\end{array}$ & $\begin{array}{c}0.07 * \\
(0.04)\end{array}$ & $\begin{array}{c}1.32 \\
(0.29)\end{array}$ \\
\hline 2004-2006 & $\begin{array}{l}-0.02 \\
(0.02)\end{array}$ & $\begin{array}{l}0.20 * * * \\
(0.04)\end{array}$ & $\begin{array}{l}0.10 * * \\
(0.05)\end{array}$ & $\begin{array}{c}0.97 \\
(0.21)\end{array}$ \\
\hline
\end{tabular}

Notes: (i) $* p<0.10, * * p<0.05, * * * p<0.01$. (ii) Cluster-robust standard errors are reported in parenthesis. (iii) Each cell in Panel 2 represents a cross-sectional regression, and we only report the coefficients of URBAN dummy here. (iv) Other control variables include child's characteristics as age, gender, nationality, and student status; household characteristics as household income, gender of household head, and household size; mother's characteristics if present in the survey, such as mother's age, height, BMI, education, employment status, smoking and drinking behavior, and an indicator for the presence of mother in the survey; father's characteristics if present in the survey, such as father's age, height, BMI, education, employment status, smoking and drinking behavior, and an indicator for the presence of father in the survey; indicators of provinces; and a constant (for continuous dependent variables), which are not reported here. 
Table 7

Urban-Rural Disparities in Child Health Status by Gender

\begin{tabular}{|c|c|c|c|c|}
\hline & \multicolumn{4}{|c|}{ Child Health and Nutritional Status } \\
\hline & $\begin{array}{l}\text { Height-for-Age } \\
\text { Z Score }\end{array}$ & $\begin{array}{l}\text { Weight-for-Age } \\
\text { Z Score }\end{array}$ & Stunted & Underweight \\
\hline \multirow[t]{2}{*}{ Panel 1.} & \multicolumn{4}{|c|}{$\begin{array}{l}\text { Multivariate Analyses with Interaction Terms between URBAN Dummy } \\
\text { and Gender }\end{array}$} \\
\hline & Coef, & Coef, & Odds Ratio & Odds Ratio \\
\hline Urban & $\begin{array}{l}0.30 * * * \\
(0.05)\end{array}$ & $\begin{array}{l}0.22 * * * \\
(0.04)\end{array}$ & $\begin{array}{l}0.63 * * * \\
(0.08)\end{array}$ & $\begin{array}{c}0.83 \\
(0.21)\end{array}$ \\
\hline Urban×Girl & $\begin{array}{l}-0.04 \\
(0.06)\end{array}$ & $\begin{array}{l}-0.08^{*} \\
(0.04)\end{array}$ & $\begin{array}{c}0.99 \\
(0.16)\end{array}$ & $\begin{array}{r}0.55^{*} \\
(0.19)\end{array}$ \\
\hline Girl & $\begin{array}{c}0.05 \\
(0.03) \\
\end{array}$ & $\begin{array}{r}0.05^{*} \\
(0.03) \\
\end{array}$ & $\begin{array}{c}0.92 \\
(0.06) \\
\end{array}$ & $\begin{array}{l}1.26^{*} \\
(0.16) \\
\end{array}$ \\
\hline $\begin{array}{l}\text { Observations } \\
\text { (Pseudo) } R^{2}\end{array}$ & $\begin{array}{c}13011 \\
0.25\end{array}$ & $\begin{array}{c}13011 \\
0.22 \\
\end{array}$ & $\begin{array}{c}13011 \\
0.14 \\
\end{array}$ & $\begin{array}{c}12790 \\
0.16 \\
\end{array}$ \\
\hline \multirow[t]{2}{*}{ Panel 2.} & \multicolumn{4}{|c|}{ Multivariate Analyses Separately for Boys and Girls } \\
\hline & $\begin{array}{l}\text { Coef, of } \\
\text { Urban }\end{array}$ & $\begin{array}{l}\text { Coef, of } \\
\text { Urban }\end{array}$ & $\begin{array}{c}\text { Odds Ratio of } \\
\text { Urban }\end{array}$ & $\begin{array}{c}\text { Odds Ratio of } \\
\text { Urban }\end{array}$ \\
\hline Child gender & & & & \\
\hline Girl & $\begin{array}{l}0.25 * * * \\
(0.05)\end{array}$ & $\begin{array}{l}0.15 * * * \\
(0.05)\end{array}$ & $\begin{array}{l}0.60 * * * \\
(0.09)\end{array}$ & $\begin{array}{l}0.48^{* *} \\
(0.15)\end{array}$ \\
\hline Boy & $\begin{array}{l}0.30 * * * \\
(0.05)\end{array}$ & $\begin{array}{l}0.21 * * * \\
(0.04)\end{array}$ & $\begin{array}{l}0.65 * * * \\
(0.08)\end{array}$ & $\begin{array}{c}0.75 \\
(0.21) \\
\end{array}$ \\
\hline
\end{tabular}

Notes: (i) $* p<0.10, * * p<0.05, * * * p<0.01$. (ii) Cluster-robust standard errors are reported in parenthesis. (iii) Each cell in Panel 2 represents a cross-sectional regression, and we only report the coefficients of URBAN dummy here. (iv) Other control variables include child's characteristics as age, gender, nationality, and student status; household characteristics as household income, gender of household head, and household size; mother's characteristics if present in the survey, such as mother's age, height, BMI, education, employment status, smoking and drinking behavior, and an indicator for the presence of mother in the survey; father's characteristics if present in the survey, such as father's age, height, BMI, education, employment status, smoking and drinking behavior, and an indicator for the presence of father in the survey; indicators of provinces; and a constant (for continuous dependent variables), which are not reported here. 